\title{
A Study on Arts and Crafts ideas with Works of William Morris
}

\author{
Jaehyuck Lee ${ }^{\dagger}$, Kim Cheeyong ${ }^{+\dagger}$
}

\begin{abstract}
These days there is a flow of support for returning to design and handcraft, and the arts and crafts ideas of William Morris have an influence until the present over periods. The semanticity and methodology of guild production method supported by William Morris is studied. The foundation that human is in beautiful harmony with nature is on free labor and artistic life. In the organic relationship, the decline of art is understood as general crisis of culture, and human living condition should be changed in order to rouse the human sense of beauty and comprehension of art. Once human labor becomes artistic, the consumption living and local living become artistic as well. And then consumers desire more artistic works, structures, or urban spaces, and the demands for those move artificers to go toward producing more artistic works and structures. That is, the course of succession of art and culture through living is the driving force of social progress. Even if the period when Morris lived and the present are very different, this paper will shows that a large amount of art and culture will be greatly developed in twenty-first century which is 'the period led by cultural consumers', and the people directly creating art works will be also increased at the same time, as Alvin Toffler suggested. Furthermore, we can aware through this paper that such the people will rule the world. Finally it reached the period that we must face to 'making artistic life' as Morris expected a century ago. According to the result of this paper, we realized the study about Morris will contribute greatly to improve the quality of human life.
\end{abstract}

Key words: William Morris, Arts and Craft, Guild

\section{INTRODUCTION}

\subsection{Purpose of the study}

The core of William Morris' ideas for arts and crafts can be summarized as a criticism of mass production system in industrial age and rejection of commercialization. William Morris tried to overcome the negativity from mechanical age through a guild of the middle ages.

* Corresponding Author: Kim Cheeyong, Address: (614-714) 176 Eomgwang-ro, Jin-gu Busan, Dept. of Visual Information Engineering, Dong-Eui University, TEL : +82-10-4584-4036, FAX : +82-51-890-2265, E-mail :kimchee@deu.ac.kr

Receipt date: September 08, 2013, Revision date: September 22, 2013, Approval date : September 22, 2013

${ }^{+}$Dept. of Formative Design, Kyunghee University (E-mail: ohholee@hanmail.net)

${ }^{++}$Dept. of Visual Information Engineering, Dong-Eui University
The positivity that William Morris found through the guild was a freedom for artificers to use their imagination on the basis of their own abilities as one artificer produces one work from the beginning to end of whole process in a production system. William Morris thought the form of guild is the most ideal labor pattern.

A guild is considered as the legacy of the old days, but it remains in existence. In other words, it is still effective on the arts and crafts that manual production is the center of the production method. 'Apprentice' could be defined as a kind of guild.

It may be decided that a crisis of modern craft has been already generalized as the reliance for market has been getting intensified. It is true the base of existence is dangerous other than a production of works which meet the demands.

However, the crisis of mass production system is on everybody's lips, and the sustainable develop- 
ment became a major concern as a global agenda Modern craft alone shows the flow of support for returning for design and hand craft, and we guess the demand would be stronger in the future. Estimating William Morris's research and its limit is closely connected with a change of flow of the times like above.

\subsection{Method and range of study}

We would like to research William Morris' life, ideas, and the historical background and study the William Morris' semanticity and methodology of guild production method supported independently with his ideology of socialism in order to think about the right direction of Korean handcraft. Therefore, we would like to arrange a suitable topic of the subject through related documents and analysis of data.

\section{Arts and crafts in 19th century and the type and analysis of works by William Morris}

The artistic ideas of Morris were based on the special state of a period called Victorian age in England(Generally means the period of Queen Victoria's resign) At that time, there were social changes in England by external influence of the French Revolution and internal influence of the industrial Revolution, and then a new class named 'bourgeoisie' which has primary base on 'wealth' appeared as the individual freedom and political expression was getting expanded, and the industrial economy was developed.

The Industrial Revolution which lasted for 100years gave both of wealth and poverty at the same time to people of Victorian age. The Industrial Revolution brought the accretion of wealth to England, but it needed sacrifices of workers with low wages and excessive working hours. So the positive reviews and criticisms for the society at the time should have been coexisting, and Morris came forward as the strong critic.

Artificers gathered to factories after handcrafts replaced industrial products, and they became a part of the completely mechanized factories. Also they should have taken demands of the market above all requirements. Design of industrial products became regardless of artificers who made the products, and they just manufactured the same products in the factories.

Morris considered this situation made the industrial products to be crude and decorative with low-techniques, and as the result, the aesthetic quality declined as well as public interest. Therefore, Morris had an interest in the production method of handcraft as one of alternatives for re $^{-}$ storing beauty of beauty. He regarded the touch of artificer as important.

However, Morris didn't completely exclude machinery. Although he thought handwork is a basic type for production of everyday objects, but he also paid attention to usefulness of machinery. "Machinery can be blessed as much as it is cursed. A defect of machinery only occurs when it takes away the pleasures which make people elevate and make their lives joyful from people."

"If the mechanical works are required, it is not for cheap labor but shortening the time for the labor." In other words, "Machinery will be continuously developed with labor-saving purpose, and many people will have enough spare time to taste the pleasure of life."

Also Morris thought art was collapsed by 'art for art's sake'. Because he thought art became an exclusive property of few people such as critics and artists themselves rather than many people with such the view of art. He believed "Only a small people pretend to understand and be moved for the works consisting of words which can be understood by artists. Also the works are too hostile to many people to move their hearts." Also he believed "In on word, such the common idea is a part of flatters for geniuses." Therefore in his opinion, 
art should be an object which can be shared by every person. Thus the isolated art from the public is never desirable, and "Art should be owned by the public for the public's sake." That is, it is the opinion that when art is owned by the public, $\mathrm{ev}^{-}$ eryone can share it.

As a result, Morris emphasized on the importance of handwork rather than mechanical work and pay attention to a side of art which is available for being shared by the public. Consequently, he considered handcraft as one of alternatives which can improve the aesthetic quality of everyday objects and can be liked by everyone[1].

\subsection{Craft arts in 19th century and the expansion of artistic concept}

Despite many resistances from both sides of pure art and craft art, the new craft method as art started to rule major organizations and magazines of craft art as well as dept. of arts and crafts of a college of fine arts soon. As John Ferro mentioned in 1970s, the line separating art and crafts was 'dotted line'. Reaction of the audience to the nationwide symposium named 'criticism of arts and crafts' in 1992 was surprising. The people who declared "Arts and crafts are the art" caught applause.

Almost pro-art craftsmen were outstanding technicians, but they treated the importance of techniques lightly and refused traditional types and considered its function as unessential. Perforated pots, cups which can't contain water, chairs which can't sit, and books which can't be opened became a general feature representing the arts and crafts as an art. Authur C. Danto, a philosopher argued more delicately that changing craftworks to arts is not the refusal of the function itself but the sense of identity which raises the standard from just well-made or useful level to important level.

In the view of pro-crafts, the meaning or pleas- $^{-}$ ure caused by furniture or quilt works was considered to be deeply related to human relation, not to be only self-referential[2].

We commonly call ceramics or knots as crafts. Korean dictionaries explain craft as 'Techniques or products improving the original function and harmonize the aesthetic quality, and also it is explained as 'Especially making things skillfully with your hands.' That is, craft means handicraft.

However, what we call 'craft' nowadays became 'Arts and Crafts' consisting of the words, craft meaning dexterity and art. This term was made by Morris. This concept was developed to a word 'Industrial Arts' and understood as Arts and Crafts so far.

Arts and Crafts and design are different words but also closely associated with each other. Arts and Crafts mean that one or more people make something from idea to completion by themselves, but design means mass production with corresponding designs in factories by manufacturer. In other words in case of Arts and Crafts, generally it doesn't have a separation of labor, but in case of design, the labor is separated for designers and producers[3].

\subsubsection{Expansion of artistic concept}

The general concept of art that we know is established in 18th century. The meaning of art appeared in various way according to the periods. The Arts and Crafts and some studies were included in the concept of art and excluded later, and poetry was excluded at first and included in art later. But after Charles Batteux, the meaning of art started to be fixed.

In Greek period, 'Technē', the etymology of 'Art' was used. It has the meaning of general human production activity', and it is the skill which accomplish something requiring outstanding and special ability. It includes a kind of techniques to make ship, bed, clothe, and ceramics, and techniques to rule the armies and construct buildings. The meaning of 'Technē was clearly defined by Platon, and he classified the general techniques as 
'achieved one' and 'produced one' on 『Sophist』. The achieved technique includes extensive functions such as carpentering, painting, weaving, embroidery, construction, and furniture production, so Platon didn't distinguish between fine arts from practical arts.

Bernard Bosanquet paid attention to a concept of art in Greek period on ${ }^{『} \mathrm{~A}$ History of Aesthetic like following. "It didn't made a mistake which can be barely made by modern aesthetic that doesn't accept Lesser arts or arts and crafts as things within the range of beauty."

Arts and crafts, trade, and pure art were called as same one word and considered as rational, sys ${ }^{-}$ temic and active things. So when such activities take the type of objects appealing to senses, they were always considered as things within the range of semantics by Greek philosophers.

Likewise, Tomas Aquinas 'included various techniques and arts and crafts such as cooking, battle, dressage, and law in the range of art. Also he assorted the art as two modern predicates, 'decorative one' and 'functional one'. He gave the latter superiority and believed the functional one is the right duty of the art.

On this wise, the art recognized in ancient and Middle age has much wider range than today'. At that time, 'the concept of art included both of pure arts and arts and crafts." Therefore, painting and making suits were in the same range of the art. Not only for technical production was called as 'art', the producing technique itself, acquisition of the rules, and expertise were also called as art.

As a result, grammar and logic could be included in art as a series of rules and professional skills as well as painting or making suits. In that way, art has wider range for a while. So to speak, it was due to joining of handicraft and some studies. It means ancient philosophers and Scholastics in Middle age made connection between pure art and practical art rather than separating them. They just thought separately whether the practice of fine arts requires mental efforts only or physical efforts as well.

Arts and crafts and studies excepted from the territory of art in Renaissance age. The works separating pure art from arts and crafts was promoted by the social state, the desires of artists who tried to raise their social position. Painters, sculptors and constructers were credited for their merits as Renaissance age highly appreciated for beauty. At that time, they were considered more superior to craftsmen.

Charles Batteux (1713-1780) firmed up this trend in 1747 . He admitted only painting, sculpture, music, poetry, and dance as the real art and regarded others as functional techniques. From the middle of 18th century, arts and crafts were no longer an art.

What were included in the concept of art established by Batteux became real art, and the concept of pure art as 'independent one' became the center of the aesthetic idea. H. Osborne thinks that this separation has been placed until today as a common idea.

Morris suggested the concept of greater art and lesser art as a strategy for expansion of the concept of art. Greater Arts means the pure art mentioned by Battuex, and lesser art is the concept referring 'decorative one' according to the expression of Morris.

The lesser art mentioned by Morris includes everyday objects as well as general decorative art. Therefore, houses, furniture, kitchen appliances, clothes are included in it. For example, Morris described that "because costume art is one of lesser arts, and a properly handled fabric is a live object presenting continuous activities of beauty" and "If we lost it, we would lose the half of pleasure for eyes in our daily life" on 'The Lesser Arts of Life'. Also Morris pointed out that "People don't recognize that daily necessities can be the work of art." So the concept of lesser arts suggested by Morris includes the daily necessities in the territory of art. 
The expansion of artistic concept by Morris made many of extrinsic objects including daily necessities acquire the position of art. Also it expands the range of the works of art. The question, 'what is works of art?' is the continuous task and matter of the concept of art to a estheticians.

\subsubsection{Arts and crafts movement}

In 19th century, Arts and Crafts Movement started with motto of handicraft production in England. Morris found the new decoration style from guild sand gothic formal languages of Middle age to seek an innovation of handicraft. That is, he asserted that fine arts and crafts should be combined; instead fine arts, crafts, and designs are separated. The arts and crafts movement against the industrial mechanism insisted that artificers have to work for the public, create beauty by hand-making with pleasure, and save the society through art. This movement is over various fields of structure, interior design, metal craft, furniture, fabric, carpet, wallpaper, font design, and glass rather than being based on a fixed modeling format.

Arts and crafts movement was spread to the European Continent and transmitted by art nouveau in 1990s which advocated new art for the new age. Morris' theoretical opinion and format had an important effect on the development of art nouveau movement later, and it was one of the biggest starting points of modern design movement. Due to the aftereffect of arts and crafts movement, modern design sought strategy for the progress of industrialization via art nouveau and multilateral possibility to combination of art and industry through the education system of Art Deco and Bauhaus [4,5].

\subsection{Practical purpose of arts and crafts and pleasure of the production process}

The practical interest in art is for the effect which believed it is from the purpose of contribution of art works and practical purpose of artworks. Through most parts of human history, art used to be planned for using on a purpose of a society like other industrial products. And there was a period that this practical interest for the purpose of art is the most common, and fundamental in some senses.

The usefulness mentioned by Morris doesn't mean simply the functional aspect only. If so, what is the usefulness of art insisted by Morris? We can find the meaning of it from the discussion about greater art and lesser art.

Morris thought that we can get real artistic works by mutual exchange between the beauty which is regarded as important in greater art and the important aspect in lesser art. It means art has to be excellent in aesthetic aspect as well as in the functional aspect. Even he advised that "You don't have to place what you don't believe it is useful or beautiful in your house." In addition, Morris exalted that construction with useful and aesthetic appearance and interior is the art work implying beauty and usefulness.

The meaning of artistic usefulness to Morris is what provides rest or pleasure to functional and aesthetic aspects. For him, it is finally the purpose of art. Ultimately, art makes lives of social members abundant. And such the ability of art is made from the fact that the artistic possibility has $\mathrm{ex}^{-}$ isted in various kinds of human activities.

Now we clearly understand Morris didn't accept the art as only the expression of emotions and noble ideas described in painting, sculpture, literature, music, and construction works. He recognized the each genre of arts as the root increasing human happiness.

Also Morris believed decorative art and craft can save humankind from social ills of that time rather than pure art. Mankind can be saved through the direct effect of genre of art other than pure art, instead of the works containing moral reformation and educative contents receiving attention as the usefulness of pure art. In short, every extrinsic 
thing of living makes it possible by service for the actual purpose.

\subsection{Reappraisal of guilds in the Middle Ages- Artistic producers as working people}

As concepts of art changed for each period, the concept of artist changed from ancient Greek to 19 th century. Johnsondescribedaconceptofartiston ${ }^{『}$ Aestheticism』as following. The concept of 'artist' was made by people in 19th century. Before 19th century, an 'artist' meant a person who is well - versed in so-called 'The Liberal Arts', namely a person who has erudition and wide refinement or a person who has a special skill regardless of whether he/she is creative or not.

Various kinds of people such as poet, painter, doctor, mason, and astronomer can be included in the word. However, creative artists were commonly regarded as the people consisting in a specific separate class in 19th century, and the word, 'artist' had any special and even commonly honorable meaning. The concept of artist which changed the social position of artists strengthened the place during Renaissance age that the concept of scholar or scientist was strengthened. Then it settled down as the concept of 'genius' in 19th century.

Artists recognized as special people, and their art works became special as much as the products of geniuses. The art of Morris became for a few number of people and extravagance of minority of the rich as he criticized[3]. Morris formed the interval between the public and art, and the situation that artists shout 'art for art's sake' has been caused. Also it was far from the art which has to seek the increase of happiness.

The Morris' concept of art was based on the $\mathrm{so}^{-}$ cial situation in England, 19th century. He decided the destruction of nature and filthy living condition from very poor design and industrialization is too severe to be restored.

Morris accepted this extrinsic aspect of living in the territory of art and requested for improvement of art to the society. Finally this can be considered as the request for social improvement. Therefore, art includes the demand for social improvement in the duty of increase of human happiness. Of course the improvement doesn't mean big and great social reformation. It starts from the insignificant parts such as the furniture arrangement in a house, the color of curtains, and flowers of a garden in our lives.

This Morris' concept of art has been a proposal of new direction for industrial art since 19th century and has provided us the new cognitions about arts. Also we can read his effort for harmony of function and beauty which are the basic doctrine of modern design in his work place consisted of the forms of guild in Middle Age and factory.

The keen resistance of Socialism to extreme capitalism by the Industrial Revolution in the middle of 19th century was started by John Ruskin, but Morris showed its zenith. He believed the way to save human from the servitude of capital and machinery is the spirit of craft. He thought that works without labor is imperfect art, and only one real artis the living art by working people. So he found Gothic art in the Middle Age as his typical model. It meant freedom from classical and noble ceremoniousness, a reformation of new manufacturer class, and renovation from medieval collapse. He defined the extreme commercialism, bureaucracy, and pragmatism as decadences and emphasized a necessity of their reformation.

The socialistic tradition advocated by Morris was transmitted to Bauhaus. Gropius who made Bauhause realized the high class arts hanging on the wall of fancy museums are meaningless to poor people and tried to find a possibility of new democ ${ }^{-}$ ratization of art from designs[6].

William Morris discarded pure arts and admired the master artisans and their ideology. Morris established the philosophy of art called democratization of art and recommended painters and 
sculptors to work for the public, not for the rich Michel Ragon-Living without industry is a sin, and industry without art is barbarism - John Ruskin[7].

It is important that the modern movement is the result of combination of the Morris' movement, the development of steel construction, and 'art nouveau[8].

The people called as 'art-worker' by Schmiechen were a new type of masters, not the craftsmen in old workplaces or autonomous artists. They were elites with skills comparing with most factory workers, but their operation pace and duties were subordinate to requirements of the employer. Especially the designers working under extrinsic contracts were certainly and generally separated with art-workers who were in charge of middle process for application in the factory. Even those designers couldn't be treated as independent artist-creators.

As the difference between artists and craftsmen was getting bigger, the tension in the construction field which was included in pure art but still considered as same as craft for the aspect that it is worked for purposes was being increased.

People who regarded constructors as artists in 19th century thought metal, glass, and reinforced concrete are just a new chance for artistic expression of each individual. Demands for traditional craft techniques of skilled stone sculptors, furniture producers, and wood sculptors were decreased.

On this wise, demand for versatile craftsmen was gradually reduced in construction art as same as ceramics, weaving, and glassblowing field. The ideal of artists reached new mental height via 19th century, and there was a surplus of techniques of craftsmen. The difference of image and social position between artists and masters became wider than before[2].

Yanagi Muneyoshi insisted that we have to inform individual craftsmen, who are breaking individualism and living in social consciousness, so to speak craftsmen who lost their place named tradition and are wandering after they 'came out of the small room of individuality and their own workshop', about 'what the right art work is'. Also he said "Society can't be beautiful during works are on the hands of individuals", "The beauty which only appears by cooperation promises more happiness to the society rather than the beauty which only appears alone" and recommended individual craftsmen to raise the position for them and the public as well rather than raise their position only" [8].

\subsection{The arts and crafts ideas of Morris}

Morris formed the ultimate combination in the dialectical development process of utopia that human tries to live like a decent human with the nature in harmony. The foundations of the utopia so $^{-}$ ciety he thought were free labor and artistic life. He emphasized that the labor is a creative behavior according to free will of each individual, and it doesn't have to be a pain. It is that human under capitalistic system thinks it is useful because the labor can be changed to a material value. Art means the principle of resistance making workers resist to industrialization which make the labor named arts useless and live their real lives to Morris. That is, arts ultimately have to be the behavior expressing the pleasure of labor. It is connected with Morris' creative socialistic idea as the comprehensive theory of living at the same time.

Morris left significant achievements as an artist, but also he is recognized as the most important leader of socialistic movements in later 19th century in political aspect. He was the theorist and doer who did his very best for implementation of socialism for all his life. Especially his socialistic idea was more creative and revolutionary than any other people.

As he generally expressed his idea through lectures without remaining any systemic written theory, his socialistic movement was practical 
based on the keen sense for movement. He argued field-living socialism, neither of socialism of aloof poet nor the socialism of prideful and naïve academic professor. It was the most comprehensive and modern socialism rounded education matters, environmental matters, and sexual matters including arts. It was simply the intelligence for whole people.

Like this, his all activities which can be summarized as activities of author, artist, and socialist were never subordinate or less qualified comparing with other things but continuously collected to pursue a one spirit[6].

Morris' socialism didn't intent to make the world only for artists or to make the world created by a few gifted popular artists. It can be realized when whole people have the real view of popular arts that everyone can create and share the arts in life and society. So Morris always concerned of how we can make our lives 'hopeful, beautiful and lovely' and how we would make the society available for that [6].

Morris wasn't born with talent, but he was the best hard worker in desire of accomplishment. So he tested his own ability in various aspects such as literature, art, and design. He tried to make his simple dram and hope with modest attitude, 'As I can' for his whole life. He did his best for his interesting field, but his final goal was to make human living beautifully and naturally, in short it was the making artistic life and naturalization of life.

Morris is well known for one of the greatest designers of all time as well as in 19th century that he lived.

Calling Morris as a designer is for extensive meaning of 'a planner, an originator, or a projector'. Of course the range includes the construction environment and the accessories in it. That is, it means a person who decorates interior, plans for whole crafts, and projects and supervises everything as well as an architect designing the structure of the house. According to the concept of Morris, con- struction must be received the baptism of design since it is the fruit of arts with totality[6]. Morris was also the CEO of a company produced stained glass, wall paper, weaving, carpet, tapestry, furniture, and ceramic as well as the designer of construction design.

\subsection{Formative analysis for the type of Morris' artworks}

In the beauty area of crafts, Ruskin or Morris is the pioneer in ideological aspect. But Japanese 'early tea producers' can be the pioneers who 'recognized the beauty from crude objects first' in the territory of appreciation. It was described, "I feel unstinted admiration for their intuition and appreciation". Moreover, it was pointed out "there is no doubt that the beauty of craft viewed by early tea producers is much deeper internally than the beauty viewed by Morris" and emphasized the Japanese have much better intuition to find out the nature of beauty.

Yanagi says repeatedly that Morris "started similar movement, but he didn't know the right beauty of crafts in the world"[2].

2.5.1 Statement of crafts and understanding of William Morris in 19th century

William Morris appeared as a poet in this world at first and worked as a socialist, designer, CEO of Morris trading company, and a lecturer of social issues and arts. Also he is well-known to us as a person who played a leading role in the arts and crafts movement. The term, arts and crafts movement we are known very well is started being used by Thomas Cobden-Sanderson(1840-1922), a member of Art and Craft Exhibition Society in 1888[1].

Morris thought handicraft has to be restored as the change from handicrafts to industrial products caused to produce ugly goods only. Arts and crafts movement was a series of movement which was formed by the idea of Morris and his influence. 
Peter Stansky calls such the influence as Morrisism. Also Morris was interested in Middle Age and revival of handicrafts because he thought the most active period for handicrafts was Middle Age. He decided the form of 'guild' can be the standard of art production, and he enjoyed reading Romance of the Middle Age, used medieval motif for his works, and followed the form of guilds of the Middle Age for the workshop of Morris trading company.

\subsubsection{Typography of William Morris}

Typography is a formative transmission for printing[3].

Morris started to design his first print in Dec. 1888. It was not surprising that he decided to handle graphic design and printing because he had been interested in books for a long time. He had a few of very valuable manuscript of the Middle Age and Incunabula. Morris produced many of manuscripts consisted of the body with beautiful and skilled touch, delicate edges, and decorations with the first letters using flexible forms and vivid colors. Golden font was based on the Venetian roman designed by Nicolas Jenson in between 1470-1476. Morris drew the font repeatedly studying the large-sized picture of Jenson's font. When the amending work for the final design was completed, the essence of Jenson's font was caught in it, and it was not just a cheap imitation. The type casting of Golden font was started in Dec. 1890[9].

\section{THE ARTSAN BEINGANAD EDINBURGH WILLIAM MO 'Applied Art' is th chosen for that port speak to you about.}

picture 1

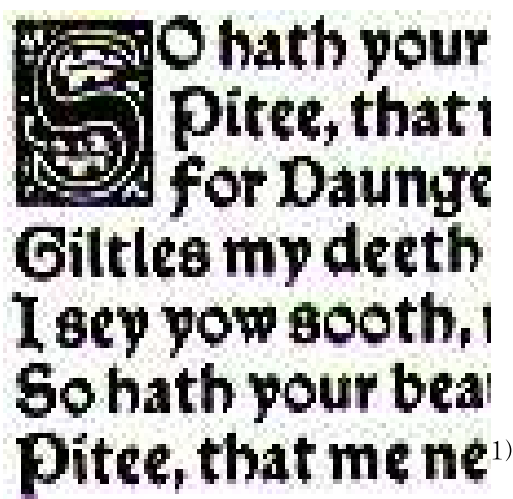

picture 2

Letter founders were hired, and a manual type printer from a warehouse of another printing company was installed in a small rental house that Morris purchased near Kelmscott in Hammersmith as a country house.

The first work of Kelmscott was the ${ }^{『}$ The Story of the Glittering Plain』 written by Willam Morris and illustrated by Walter crane. It was going to print 20 copies but it was increased to 200 paper copies and 6 high-quality forrel copies as the news of the printing spreads. Kelmscott had printed total 10,800 copies for 53 books from 1981 until it was closed in 1898, 2 years later Morris died

Morris studied Incunabula's Gothic typefaces of Peter Schoeffer, Anton Koberger, and Gunther Zainer with the greatest care and got 'Troy' font which is surprisingly easy to read.

He made the types which are wider than most of Gothic fonts, have more intensified distinction between similar types, and have rounder curves. One of the last three fonts designed by Morris was 'Chaucer' which was a miniature of Troy font. These fonts sparked interest in Jensen and Gothic fonts and caused many applied fonts of them in Europe and U.S.

1888-90, once the design of alphabet appeared in public, the interest in the font style of 'Venetian'

1) Picture 1, 2: A page of ${ }^{\top}$ The Story of the Glittering Plain』written by Willam Morris and illustrated by Walter crane. 1894. - Rosen weld Collection of The Library of Congress- 


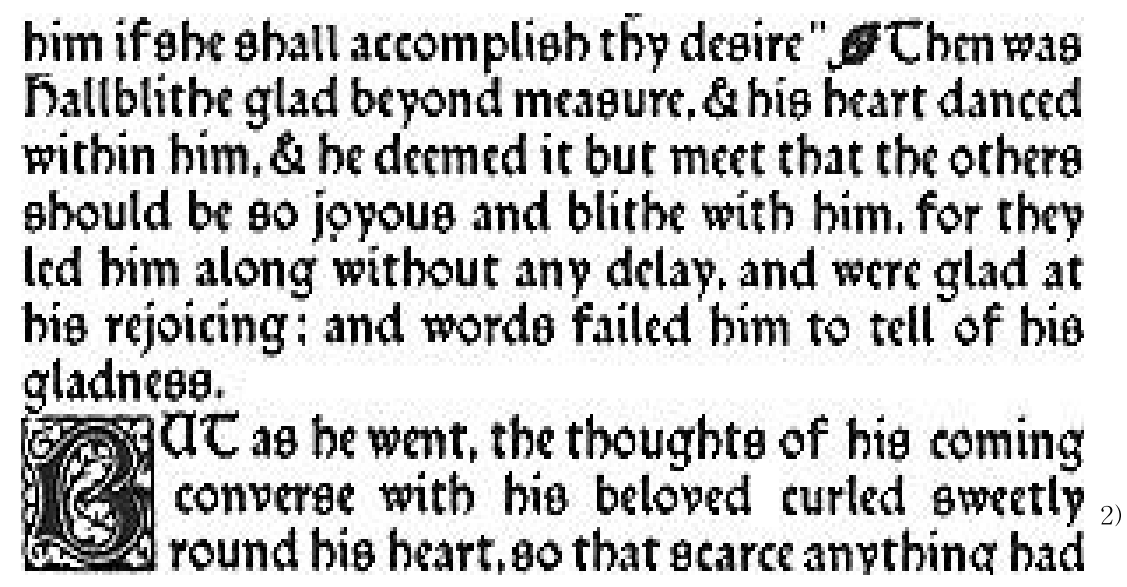

picture 3

and 'Old' was newly arose. These past fonts started being studied by designers, letter founders, and printers again.

As we can see in the layout of this page, Morris regarded lesibility as important as much as decorations. He placed considerable blank space at the edges in pages written by Troy font.

Two kind of beautiful pages were created due to the titles designed by Morris for the books, decorative types over 200, and captions in blanks and proper space between the lines, and it acquired the order and clarity to help easy reading of people.

\subsubsection{Outcome of William Morris}

\subsubsection{Living Art}

To sum up the opinion of Morris through his lecture in Dec. 1877 as one word, it would be the 'recovery of living art', and it is same as 'revival of construction.' Contrary to other ideologists of revival, he suggested real renewal of construction as living art. As his design activities were from close historical researches and nature researches, his idea was also from the understanding of the history with nature[6].

'Artists are isolated from daily life and obsessed by Greek and Italian fantasy. Even a few people are just pretending to understand them. I don't

2) Pircure 3: A page of 『The Works of Geoffrey Chaucer, The Story of the Glittering Plain』 produced by William Morris, 1896 want arts for a minority. I don't' want freedom or education for a minority in the same way. What good is art if all people can't share it?' From this critical mind, Morris thought living art has to be for everyone. The living arts, which are produced to make producers or users happy, produced by the public and for the public is the root of all kinds of $\operatorname{arts}[6]$.

\subsubsection{Interior decoration}

It was summer of 1956 when Morris was interested in interior decoration, and it was the chance that he made furniture by himself when he gave up the construction study and lent a studio in London with Burne Johns. Then he experienced the pleasure of joint arts for the first time during he painted on the wall of Union in Oxford and became the supervisor of order for tools to learn the basic of planning and systematization. In 1861, Morris established 'Morris, Marshall, Faulkner Company' specializing in the interior decoration with his friends. At that time, the prospectus of the company included the paragraph of "Wall decoration by painting for houses, churches, and public construction or combination of colors"[6].

\subsubsection{Furniture design}

The early designed products by Morris Company were mainly designed by Philip Webb and had very simple and upright impression. Also they 
never gave comfortable feeling as they were too heavy to move. Actually Morris didn't care about comfortable at all from the first. He said, "Take a rest on the bed, if you want to be comfortable."

The 'Sussex chair' designed by Philip Webb produced from about 1860 had same style. This chair was made by changing traditional folk crafts and gave light feeling with rush material of the seat. Like this, Morris prefer to the design relying on handwork with such the rush material.

The formative beauty by handwork is the basic philosophy permeated into the products of Morris Company. Morris believed handwork has the original pleasure of labor and was convinced that more beautiful and nice products can be made from handwork rather than machinery. Therefore, handwork of Morris was the result according to artistic conscience as a public figure[6].

\subsubsection{Wall paper design}

The initial wall paper designed by Morris in 1862 was medieval and pastoral. The flowers, fruits, and leaves painted on the wall paper were naturally flat with immortal impression. Also it gave strong feeling by its simple but highly formalized design. Fabric design is also same with that. In a word, his wall paper design is 'Design of naturalism'.

We can feel Morris who regarded handworks of weavers in the Middle Age as noble when we look at the hand-made wall papers using 30 sheets of woodblock according to each pattern. Although they has been designed a century ago, but they give us the modern sense making our lives more energetic instead they seem to have old fashion [6].

Morris had an interest in embroidery as well so that he decorated his studio in London with embroidered hanger in 1856 . It was because embroidery didn't need any special tools or techniques but brush, thread, and needle to make products by handwork.

\subsubsection{Construction}

Morris took construction classes about a year only in Oxford, and he never designed and built a building before. However, he was recorded as a person who has a great effect on modern construction history over 100years.

He always felt the necessity of construction in the frame of his thinking or design. Construction means 'a foundation of every art', 'a synonym of applied arts', and 'the best work which can be made by cooperation between people' to Morris. Its headstream was the Gothic construction, so he put stress on the basic foundation which made the Gothic construction possible.

The concept of Morris' construction doesn't mean just a combination of various arts with arithmetical calculation. He thought construction in the aspect of 'popular arts'. He contended that "we can make valuable arts for everything using a few tools for expressing the thoughts and hopes in our mind without any great tools or good materials"[6].

\section{Arts and Crafts Idea of William Morris influencing on modern crafts and designs}

\subsection{Return to handicraft tradition}

It is almost same between what Morris and Kropotkin pursued and the goal that we are pursuing in reality. Their bodies lived in 19th century, but their spirits are living in 20th century. The dream of the new world Morris suggested is gradually coming true in the present[6].

Hazel Henderson, James Robertson, Walt Schwartz, and Dorothy Schwartz insisted that the ideal society Morris pursued on $『$ The utopia new $\mathrm{S} \Omega$ showed the symptoms in the western world in 20th century, and it predicted the advent of later industrial society which regards environmental is ${ }^{-}$ sues as important above all things.

Especially the Morris' belief that "We have to make products keeping the best quality as much as possible and to minimize the ecological damage according to the production at the same time, and 
the producer should be satisfied with the works" contributed greatly to form the mainstream of 'Green' ideas today[6].

In later 1950s, neo-dada and pop artists started the tests with timber, clay, fabric, resin, and synthetic resins. Some potters such as Peter Voulkos introduced the expressionistic method into the glost process. Voulkos made several necks or odd shape sticked up and made holes on pots in order to make them useless as pots. The group including Voulkos was called as 'pottery sculptors' rather than 'potters' or 'craftsmen' soon.

The similar transformation was happened in other craft works. The abstract and three dimensional works of Lenore Tawney, Sheilla Higgs, and Claire Zeisler changed just 'fabric' to the 'textile art'. Handicrafts furniture was changed to 'art furniture' by people who have various views such as Sam Maloof, Wendell Castle, and Richard Artschwager. They continuously made from very functional one to almost useless one. The big turning point of glass crafts happened in 1962 that Harry Littleton introduced a kiln of same size with his workshop, and 'glass art' appeared, and then it was connected to the work of Dale Chihuly which was reached to the kind of defied pure formation[2].

\subsection{Recovery of human being by pleasure of labor}

To produce artworks means labor to Morris. It was not special thing to make artworks for him since he thought it is not for someone special who was given the talent, but it can be done by anyone through an education. As we examined previously, as the concept and the purpose of art, the extrinsic objects which can increase our happiness such as cups, plates, clothes, furniture, and gardens are just fruits of labor, not the creations of genius or someone who was given the inspiration. For Morris, labor was the reason of the existence of art. That is, labor exists if there is art, and art doesn't exist if labor doesn't.
However, Morris didn't thought simply the labor is same as production of arts. He thought labor has to accompany pleasure in order to be a producing activity for arts, and that's the view that the production of art is joyful labor. Therefore, Morris didn't understand the production activity of art with economic or political theories, but he just understood it expresses the pleasure of living, so it is the activity with pleasure.

Thus, he is different from Marx who considered every human activity as the result or expression of economic statement, but he didn't deny that labor is essential activity for living. He understood the inevitable motif of labor should include more important motifs such as 'interest and pleasure for labor itself' other than for maintenance of livelihood. Morris said like following,

"Work can be more pleasant if more people can work around their houses, and the distinction between home and work place disappears. Small workshops would replace factories and circulate relatively less specialized tasks than others. Machinery actually saves labor and releases laborer from boring and hard works."

In utopia, products are made according to demands only, and labor is considered as pleasant. It is the basic concept of utopian economy thought by Morris. Crafts and decorative arts would be raised extensively. So this artistic promotion would put an end to the division of labor and leisure which brings all of negative changes.

Products are selected according to demands of people, nobody is interrupted to get more than he/she requested, and nobody tries to get more for tomorrow. The production for necessity, not for desire definitely meets the requirements from society removing the surplus value at the same time. Suppressing the lust for conquest for nature is for removal of surplus values. Therefore, Morris used a relative concept named 'necessity vs desire' for a possibility of realization of actual ecological society without extreme authorized law or custom[6]. 
3.3 The expansion of concept for arts, crafts, and design and mutual communication

The meaning of that the word, design is being used widely is because the meaning involved in the word is large, and it does not need to be criticized about the point specially.

The original meaning of the word, design can be separated roughly into two branches if we think about it with the explanation from a dictionary. The first meaning is 'a mental plan', and it means a plan or design supporting the realization originated in our mental. The second meaning is 'a plan in art', and it appoints the preliminary kind of sketches especially for painting production. In the view of etymological aspect, the other words meaning 'design' in different languages such as desseing, the French word which became an obsolete word or disegno, the Italian word have same original meaning, 'purpose'. Later the artistic meaning was added to the words, the French was changed its structure, so 'dessein ' means 'purpose' or 'plan', and the word meaning 'design' was changed to 'dessin', and both words are used as the meaning of design in English. Above are the meaning of 'design'as a noun, but design meaning as a verb is originated from Latin language, designare. It is divided into three meanings of the meaning 'to make out', and 'making a plan' or 'drawing a sketch' originated in two meanings of above noun.

Say the meaning of design in one word in these days; it was a plan or design for industry aiming at so-called beauty and usefulness.

Above all, it is not easy to answer the question, 'what is design?' on a moment's thought. The question is always placed on the extremity of $\mathrm{de}^{-}$ sign theory, and the answer would be different according to the arguer's concept of design such as 'What phenomenon can be considered as design?' Design basically means mapping out, but it can be understood as the process substantiating any fixed concept. To be accurate, the concept means a kind of symbol of the purpose and the internal purpose trained in the sense of people doing design activities. Finally design is nothing but speaking the polishing of substantialization for this concept. The substantialization concretely provides specific form to something, and it is a kind of crude activity. Therefore, the important things in the process for objects with shape are the concretely formed method of 'How', and to add various components to systemize them. The required ability here is so-called conception ability in Kantian meaning and also judgment as an ability to apply.

To view the design as the 'process' like mentioned, in other words, means understanding $\mathrm{de}^{-}$ sign as an activity or a phenomenon[3,10].

\section{CONCLUSION}

Morris prospected the progress of society through 'making artistic life and naturalization of life' for his whole life. In the period he lived, the effects from Industrial Revolution were permeated in everywhere in the society. People applied many inventions and the results of discoveries represented as a steam engine for their production and living to enjoy convenient and efficient life like us.

However, not like as the past, people became so busy that they lost many values which have raised them such as nature and history, friendship in childhood, a simple emotion. As people are too busy regardless of the present or the past, and the changes are too extreme, so people became chronic for any stimulation and accept unconcern and apathy as their fate.

Morris asked 'What if I can do it?' to resolve the reality and found a great value from recovery of 'lost articles' of people. However, he can't be interpreted as a romanticist with a hobby of remembrance even if he tried to recover the missing things in the past.

About that he was interested in traditional things, it can be said 'review the old and learn the 
new' in an oriental idiom.

The actual old thing was structures and crafts made by free labor of the public, instead of the palace of the king or a garden of a noble. To make higher the artistic value of spaces for labor and living was the first step of his 'making artistic life'.

Seeking the beauty of life through free labor and convenient living was the fundamental artistic spirit and also the purpose of Morris Design Company established by Morris.

That is, the combining usability and beauty was the most assignment of Morris' design. In this respect, Morris can be evaluated as a pioneer actually combined art and industry.

He insisted the human labor can be pleasant if artistic factors are included into every structures or products made by human, and that's why he insisted that machinery has to be a supporter of human, not be an owner.

It means the meaningless repetitive work ruining pride of people has to be made by machinery, but the work requiring intelligent planning or creativity has to be in charged by human. However, Morris warned that the field requiring pleasant human labor and creativity should be limited for common good of whole society, and we don't have to do foolish things such as inventing weapons which can kill or wound many people in order to look after interests of individuals or some specific classes.

Morris asked back that 'is it an artistic activity that human labor is taken to make weapons?' Finally, the contradiction such as beautiful nuclear weapon doesn't have to be existed. Followed by Carlyle, Ruskin was the first person who said the corruption of art is threatening the whole society and said about systemic relationship between art and society, and understood the corruption of art and hobby as the overall cultural crisis, and also the first person who expressed the basic principle which is not recognized enough with its value until today and insisted that we have to change the human living condition first in order to aware the hu- man sense of beauty and understanding for arts. He emphasized if we have no regard of arts, a spiritual being of any citizen would be in danger[6].

Also Morris emphasized that if human labor becomes artistic, the consumption and local life would be artistic as well. Then consumers will requires more artistic works, structures, or urban spaces, and such the desire moves producers to advance to the direction of production for making more artistic products and structures. That is, the transmission process of art and culture through living is the driving force of social progress.

The periods between us and Morris are very different, but as Elvin Toffler, the futurologist advised, mass artistic and cultural media would be greatly advanced and the people who directly cre ${ }^{-}$ ate art works will be increased.

Such the people will rule the world. As Morris predicted a century ago, the period that we have to accept the 'making artistic life' is coming. In this period, the study for Morris would be more progressed. I expect many artists who will rule this world greatly contribute to make happy world of the public based on the concept of Morris and also hope that more studies will be progressed in the future.

\section{REFERENCES}

[1] Park Hong Kyu, A Critical Biography of William Morris, Gaemagowon, Goyang, Korea, 2007.

[2] Shiner, Larry and Kim Jung Lan, The Invention of Art : A Cultural History, Book Publishing Fields, Seoul, Korea, 2007.

[3] Myeong Seung Su, The Horizons of Modern Design, Designhouse, Seoul, Korea, 1986.

[4] Yoon Min Hee, The Culture of Keywords : Design, YaeKyung, Seoul, Korea, 2003.

[5] Nailor, Gillian and Park Yeon Sil, The Arts and Crafts Movement, Chang-Mi, Seoul, 
Korea, 1995.

[6] Park Hong Kyu, The Life and Thought of William Morris, Gaemagowon, Goyang, Korea, 1998.

[7] Jeong Si Hwa, The 150 years of Industrial Design, MijinSa Seoul, Korea, 1991.

[8] Nakami Mari and Kim Soon Hee, A Critical Biography of Yanagi Muneyoshi, Published hyohyeong, Seoul, Korea, 2005.

[9] Joo Yeon Gyong, A Study on the William Morris' Book Design, Master's Thesis of Hongik University of Industrial Art, Korea, 2006.

[10] Min Gyeong Woo, A Understanding of the Design, MijinSa Seoul, Korea, 2011.

[11] Gwon Myeong Gwang and Myeong Seung-Su, The History of Modern Design, MijinSa Seoul, Korea, 1983.

[12] Chu Eung-Sik, The Study of William Morris's Handi-Crafts Movement, Master's Thesis of Kyung-Hee Univ. of Fine Art, 1990.

[13] Lee Eun-Ok, A Study on the Design Ideas of William Morris, Master's Thesis of Hyosung Women's University of Applied and Fine Arts, 1987.

[14] Park Yeon Sil, A Study on the William Morris : Modern Sense of The Arts and Crafts Movement, Master's Thesis of Hongik University of Fine Art , 1985.

[15] Kim Young-Hee, A Study on the Design Ideas of William Morris, Master's Thesis of Ewha Womans University of Education, 1976.

[16] Won-Ho Choi, Kim Cheeyong, A Study on Illusion of Digital Image, Journal of Korea Multimedia Society, Vol. 16, No. 5, May 2013.

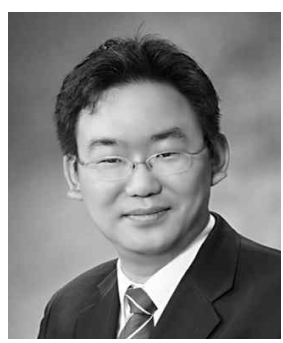

LEE Jaehyuck

LEE Jaehyuck acquired a bachelor's degree in Physics from Soonchunhyang University, a master's degree in Physical Education from the graduate school of education Kyunghee University, and He study Formative design in the graduate school of education Kyunghee University.

Now, he work in administration office of Gyeongju Middle and High Schoool from 2008.

He did not attend a lot of exhibition but He has worked steadily. And he interest in Formative Design, Ceramic arts and Educations.

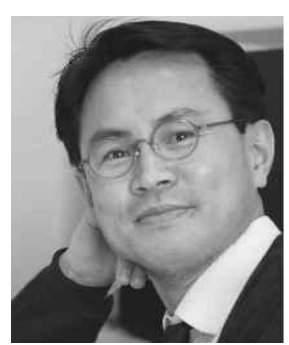

\section{KIM Cheeyong}

Professor KIM Cheeyong $\mathrm{ac}^{-}$ quired a bachelor's degree in Physics and a master's degree in Computational Physics from Inje University. He worked as a researcher at the Institute of Computer Design Education of Inje University from 1991 to 1999, full time lecturer of Department of Information and Communications at Busan Info-Tech College from 2000 to 2002, assistant professor of Department of Digital design at Dongseo University from 2003 to 2005, visiting professor at Oxford University in 2007, and visiting professor of the Digital Clothing Center at Seoul National University in 2012. Currently, he is an associate professor of Department of Visual Information Engineering at Dong-Eui University. Prof. Kim held private $\mathrm{ex}^{-}$ hibitions four times both in Seoul and China and joined over 200 international group exhibitions. With his deep interest in 3D Animation, Fractal \& Chaos Design, Computational Simulation, and 3D virtual fashion fitting, Kim passionately researches and gives presentations on the convergence of film and engineering. 